\title{
Millennials Consumers Preference towards Provided Neighborhood Facilities in Housing
}

\author{
Ni Putu Widya Oktavyani ${ }^{1}$, Dalhar Susanto ${ }^{2}$, Azrar Hadi Ramli ${ }^{3}$ \\ \{widaoktavyani@gmail.com ${ }^{1}$,dalhar3001@yahoo.com ${ }^{2}$,azrar_ind@yahoo.com ${ }^{3}$ \} \\ Architecture Department, Universitas Indonesia, Depok, 16424, Indonesia
}

\begin{abstract}
Millennials, those who were born between 1980 and 2000, are becoming the next big consumer target in house markets as they are entering the young adult age. To appeal to millennials, the developers need to understand the factors that influence their decision since housing purchase is a very complex decision-making activity. There are some factors such as economy, lifestyle, and physical factor. The physical factors have one of the key factors to inspire millenials in purchasing a house, especially neighborhood facilities. The aim of this study is to identify the types of neighborhood facilities that are highly prioritized by millennials, and examine the correlation based on socio - economic background. This study is a qualitative research with data collection by distributing an online questionnaire with open ended answers, and cross tabulation. In general, millennials have highest preference for open space, parks, and sports facilities. This research can serve as an inspiration to determine neighborhood facilities in real estate.
\end{abstract}

Keywords: preference, millennials consumer, neighborhood facility, housing, real estate.

\section{Introduction}

Generation Y, usually known as Millennials, are people who were born between 1980 and 2000 [1]. Millennials are expected to be the next big target in the real estate market as their population rate is $33,75 \%$ in Indonesia [1]. Since the millennials are now entering young adult age, most of them are still not financially stable considering the average income of millennials in Jakarta is around IDR 6 million per month. That number is lower than the average income in Jakarta; which is around IDR 8,6 million [2]. Furthermore, only $17 \%$ of millennials can afford houses [2]. This is ironic considering that millennials consumption trend is based on their lifestyle and leisure experience [3]. However, there is still a high demand for residential needs, particularly landed houses. Due to the increasingly high selling prices in the capital, many millennials prefer satellite cities, such as Bogor, Depok, Tangerang, and Bekasi as their residential areas because they can offer more affordable houses.

A house is a reflection of the owner, therefore there are various factors that complicate the decision making process of purchasing a house. One of them is the availability of facilities in the neighborhood because the facilities have an important influence on the physical condition and housing environment [4]. According to Act number 1 of 2011 on Housing and Residential Area [5], housing is a set of houses as a part of an urban or rural residential area, which is equipped with infrastructure, facilities, and public utilities as an attempt to provide a livable house. In other words, without those facilities, housing will not be perceived as perfect 
housing. On the other hand, developers mainly have the goal of gaining profit so that developers will use various strategies to increase the value of their properties. Neighborhood facilities, besides being mandatory, have become the developer's tool to increase property values.

The ever changing trend in the real estate business forces the developers to be adaptive. One of the strategies is to understand the market signals of their target consumers, or in this case, the millennials. The development in real estate is not only affected by economic factors, but also by trends and changes of demographics, as well as lifestyle [6]. In understanding market signals, market demand is also influenced by preferences [6]. A study reveals that the consumer preferences that can affect housing values are (1) design, (2) brand, (3) reputation, (4) reinvestment value, (5) facilities, and (6) accessibility [7]. Whereas another research [8] conducted in Depok concludes that the factors considered when purchasing a house are (1) price, (2) flexible payments, (3) location, (4) neighborhood facilities, and (5) the popularity of the developer. But unfortunately, the previous researches have not specifically examined the preference on the housing facilities of the millennials generation. Therefore, the objectives of this study are to identify the types of neighborhood facilities in housings preferred by the millennials, especially in Jabodetabek (Jakarta, Bogor, Depok, Tangerang, and Bekasi) through an online questionnaire, and examine the correlation based on socio-economic class.

\section{Methods}

This research used online survey data with a questionnaire. The distribution of this questionnaire used a purposive sampling technique [9]. This study used a certain range of millennials age as our criteria for selecting our respondents. This research required us to select the closest people who fell into our criteria and then asked them to share the questioners through social medias. The questionnaire was accommodated on Enalyzer website that enabled to set a pre-condition on certain questions. The data collection was conducted in limited time during the thesis research, specifically on May 1st - 4th, 2019.

\subsection{Data Collection}

Data collection was conducted through questionnaire with directed and open ended answers. The target sample size was adapted from Onwuegbuzie's opinion [10] which is minimum 64 respondents for correlational research. Each respondent has to meet the sample criteria; (1) millennial around 20 - 39 years old, (2) lives in Jabodetabek. (3) either owns a house or not.

Questionnaire Design :

a) Demographic Background

1) The initial section contained an introduction. This section focused on the number of children and income that are still considered to be related in market research of real estate. These data helped us to identify the distribution of socio-economic background of our respondents.

2) Afterward, the answers of number of children are categorized based on whether they have a child or not. For the income answers, they are categorized based on their economic classed from an income tax analysis [11] as seen in Fig.1. 


\begin{tabular}{|l|r|}
\hline \multicolumn{1}{|c|}{ income / year } & tax rate \\
\hline up to 50 million & $5 \%$ \\
\hline $50-250$ milion & $15 \%$ \\
\hline $250-500$ milion & $25 \%$ \\
\hline more than 500 milion & $30 \%$ \\
\hline
\end{tabular}

\begin{tabular}{|l|l|}
\hline 4 million per month & lower - middle \\
\hline $4-20$ million per month & middle - middle \\
\hline $20-40$ million per month & upper - middle \\
\hline more than 40 million per month & upper \\
\hline
\end{tabular}

Fig.1. Income Taxes Analysis for Economy Class Classification Source: PPh 21, 2013

b) Neighborhood Facilities

1) This section began with a description of neighborhood facilities provided by the developers. It also provided some examples of the facilities to avoid potential bias and ambiguity for the respondents who might still be unfamiliar with the term.

2) Next, is a about their preferences on neighborhood facilities. It used an open ended answer to find out what the types of neighborhood facilities that the respondents wanted.

3) Their answers were categorized based on Standar Nasional Indonesia (Indonesian National Standard, abbreviated SNI), SNI 03-1733-2004 [12], (1) cultural and recreational facility, (2) health facility, (3) education facility, (4) commercial facility, (5) worship facility, and (6) open spaces, parks, and sports fields facility.

\subsection{Data Processing}

To compile the answers of each question, they are presented in pie charts. Furthermore, a correlational analysis uses a cross tabulation by crossing the neighborhood facilities results, and the background results of income and parental status. And to facilitate the analysis, the tabulation is visualized with heat map.

\subsubsection{Coding}

In the analysis process, cross tabulation is applied separately for each category of economic background (income) and social background (family). The first part is a cross between the answers of family background (parental status) as the rows, and neighborhood facilities as the columns (fig.2). The second part is a cross between answers of economic background as the rows, and neighborhood facilities as the columns (fig.2). Neighborhood facilities are categorized as mentioned before.

\section{Rows}

\begin{tabular}{c}
$\begin{array}{c}\text { Parental } \\
\text { status }\end{array}$ \\
\hline
\end{tabular}

Income

\section{Columns}

\begin{tabular}{|c|l|}
$\begin{array}{c}\text { Neighborhood }-\cdots \\
\text { Facilities }\end{array}$ & $\begin{array}{l}\text { 1.cultural and recreational facility } \\
\text { 2.health facility } \\
\text { 3.education facility } \\
\end{array}$ \\
& 4.commercial facility \\
& 5.worship facility \\
& 6.open spaces, parks, and sports facility
\end{tabular}

3. Upper-middle class

4. Upper class

Fig.2. Rows and Columns for The Cross Tabulation Source: Personal Analysis 


\section{Results and Discussion}

At the end of the data collection, the results obtained 167 respondents but only 107 respondents managed to complete the questionare and met the sample criteria. The final number is still higher than the minimum number of target. This study sheds some lights on millennials' preferences on neighborhood facilities so the developers know what kind of facilities they need to provide for them since they will be the next big target.

\subsection{Questionnaire Results}

After an elimination process of some respondents failed to meet our sample criteria, the results compiled into pie charts. The results of the questions about age, number of children, and income from the 107 respondents can be seen in Fig. 3 below.
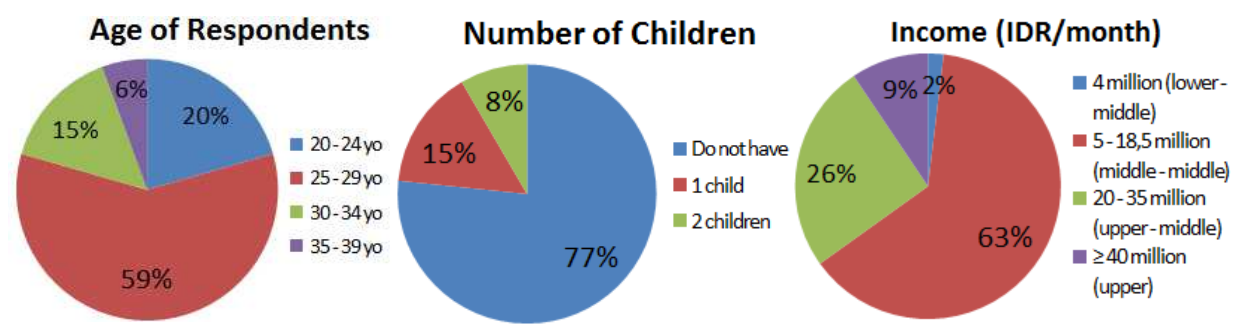

Fig.3. Questionnaire Results Diagrams of Age, Number of Children, and Income Source: Questionnaire

The first pie chart of figure 3 shows that $59 \%$ of the respondents are millennials aged 25 - 29 years old. It is then followed by $20-24$ years old with $20 \%, 30-34$ years old with $15 \%$, and $35-39$ years old with $6 \%$. The second pie chart of figure 3 then shows that $77 \%$ of respondents do not have any child, and $23 \%$ have children. This indicates that most millennial respondents do not have children at the moment. Furthermore, the third pie chart of figure 3 shows that $63 \%$ of respondents have income between IDR 5.000.000 - 18.500.000/ month which is classified as middle - middle class. It is then followed by upper - middle class millennials with $26 \%$, upper class with $9 \%$, and lower - middle class with $2 \%$.

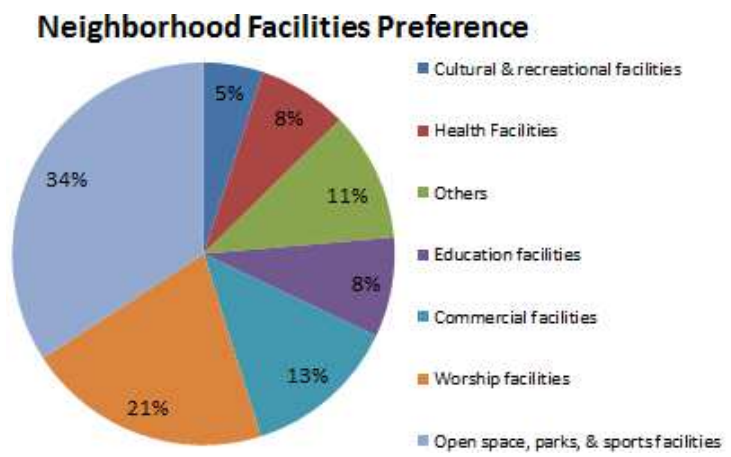

Fig.4. Questionnaire Results Diagram of Neighborhood Facilities Preference Source: Questionnaire 
Figure 4 shows that $34 \%$ of the respondents have a preference for the parks, open space and sports facilities. After that, $21 \%$ of the respondents prefer worship facilities e.g. mosques, $13 \%$ for commercial facilities, $11 \%$ for others which are not related to the terms, $8 \%$ for education facilities and health facilities, and lastly 5\% for cultural and recreational facilities. The highest rate of millennials ' preference stands for parks, open space and sports facilities.

\subsection{Cross Tabulation}

In analyzing the correlation between each category, this study uses a cross tabulation method between the types of neighborhood facilities and the socio-economic background that have an influence on housing development, such as income and parental status.

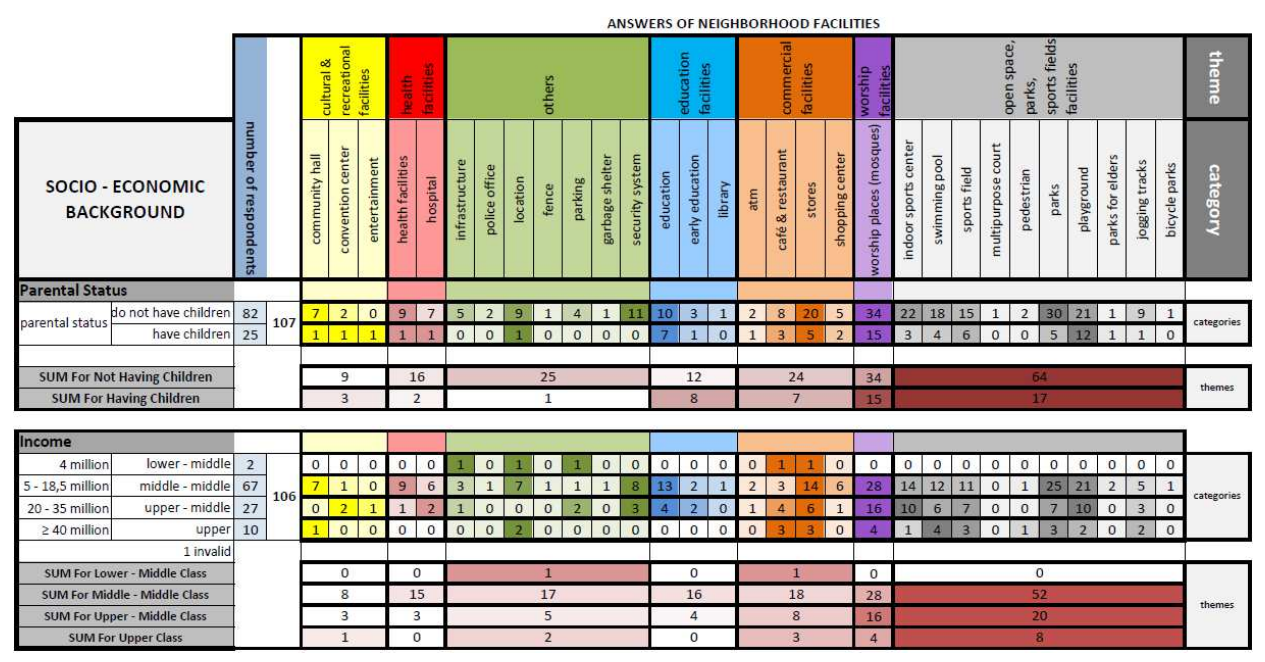

Fig 5. Resume of Cross Tabulation Source: Personal Analysis

Figure 5 shows that, in regard to parental status, the neighborhood facility of open spaces, parks and sports fields is their first preference for those who have children and do not have a child. Figure 5 also shows that in regard to the income background results, in general, respondents also have the most preference for open space, parks and sports facilities. But unfortunately, due to the low number of the respondents from the lower - middle class, it could not find out whether they share the same preference or not. From the cross tabulation, open spaces, parks and sports fields facility is the first preference for all socio - economic classes. Based on this study, millennials ' first preference on neighborhood facilities is open space, parks, and sports facilities. This result is consistent to the results of CSIS research [13] that most millennials like to do sports so they are more likely to have outdoor activities. However, cultural and recreational facilities, on the other hand, are the least desirable because they do not see social activities as a hobby. 


\section{Conclusion}

The neighborhood facilities that millennials prefer, listed from the most preferred one, are (1) open spaces, parks and sports facilities, (2) worship facilities, (3) commercial facilities, (4) education facilities, (5) health facilities, and (6) cultural and recreational facilities. Millennials ' preference for open spaces, parks and sports facilities is related to their preference for outdoor activities. Meanwhile cultural and recreational facilities are the least desirable. The results remain consistent with their hobby in their lifestyle. This research can be further developed with a higher number, especially for lower - middle class to find out whether they have the same preference or not.

\section{Acknowledgments}

This research is financially supported by Directorate of Research and Community Engagement (Direktorat Riset dan Pengabdian Masyarakat) Universitas Indonesia in PITTA B scheme grants year of 2019 [grant number NKB-0714/UN2.R3.1/HKP.05.00/2019].

\section{References}

[1] KEMENPPPA, \& BPS.: Profil Generasi Milenial. January 15, 2019. Jakarta. https://www.kemenpppa.go.id/lib/uploads/list/9acde-buku-profil-generasi-milenia.pdf. (2018)

[2] Article of Rumah123.com, and Karir.com on Desember 14, 2016.: Hanya 17\% Profesional Milenial Mampu Beli Rumah di Jakarta. January 15, 2019. Jakarta. https://blogkarir dotcom.files.wordpress.com/2016/12/rilis-hanya-17-profesional-milenial-mampu-beli-rumah-dijakarta.pdf. (2016)

[3] Bank Indonesia.: Laporan Perekonomian Indonesia 2017. Jakarta. Chapter 2. Pp 20 - 42. https://www.bi.go.id/id/publikasi/laporan-tahunan/perekonomian/Pages/LPI 2017.aspx. (2017).

[4] Alam, Md. J., and Mokbul M. A.: Public Facilities in Public and Private Housing Projects in Dhaka. Bangladesh, Urban Policy and Research, 31:2. Pp 190-207. (2013)

[5] Republik Indonesia.: Undang - Undang nomor 1 tahun 2011 tentang Perumahan dan Kawasan Permukiman. Sekretariat Negara, Jakarta. (2011).

[6] Mc Mahan, J.: Property Development: Effective Decision Making in Uncertain Times. The Kingsport Press. United States of America. Pp 75 - 131. (1976)

[7] Rahadi, R. A., Sudarso K. W., Deddy P. K., and Indra B. S.: Attributes Influencing Housing Product Value and Price in Jakarta Metropolitan Region. ITB, Bandung. (2013)

[8] Maoludyo, F. T., and Atik A.: Factor Influencing Consumer Buying Intention for Housing Unit in Depok. Journal of Business and Management, Vol.4, No.4, 2015: 484-493. (2015)

[9] Creswell, J. W.: Educational research: Planning, conducting, and evaluating quantitative and qualitative research. Upper Saddle River, NJ: Pearson Education. (2002)

[10] Onwuegbuzie, A. J., and Collins, K. M.: A Typology of Mixed Methods Sampling Designs in Social Science Research. The Qualitative Report, 12(2), 281-316. Retrieved from https://nsuworks.nova.edu/tqr/vol12/iss2/9. (2007)

[11] Direktorat Jenderal Pajak Indonesia.: Pajak Penghasilan. January 12, 2019. Jakarta. https://www.kemenkeu.go.id/sites/default/files/buku\%20pph\%20upload.pdf. (2013)

[12] Badan Standardisasi Indonesia.: SNI 03-1733-2004 tentang Perencanaan lingkungan perumahan di perkotaan. Jakarta. (2004)

[13] Centre For Strategic and International Studies.: Ada Apa dengan Milenial? Orientasi Sosial, Ekonomi, dan Politik. March 16, 2019. Jakarta. https://www.csis.or.id/uploaded 
file/event/ada_apa_dengan_milenial_paparan_survei_nasional_csis_mengenai_orientasi_ek onomi_sosial_dan_politik_generasi_milenial_indonesia_notulen.pdf. (2017) 